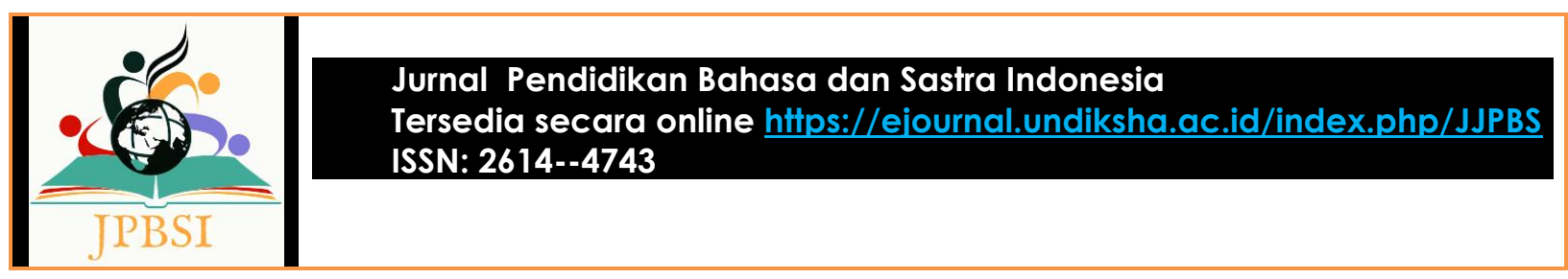

\title{
REALISASI PEMBELAJARAN DALAM JARINGAN PADA PELAJARAN BAHASA INDONESIA DI SEKOLAH MENENGAH PERTAMA
}

\author{
Savina Rachmah ${ }^{1}$, Miftakhul Huda ${ }^{2}$ \\ ${ }^{1,2}$ Program Studi Pendidikan Bahasa dan Sastra Indoesia, Universitas Muhammadiyah Surakarta \\ Surakarta, Jawa Tengah, Indoensia
}

Surel: s.rachmah2204@gmail.com ${ }^{1}$, miftakhul.huda@ums.ac.id ${ }^{2}$

\begin{tabular}{|c|c|}
\hline \multicolumn{2}{|r|}{ Abstrak } \\
\hline $\begin{array}{l}\text { Kata Kunci: daring, } \\
\text { pembelajaran, sastra }\end{array}$ & $\begin{array}{l}\text { Pembelajaran di SMP Negeri } 1 \text { Pace, masih jauh dari harapan. Banyak siswa yang } \\
\text { kurang disiplin mengumpulkan tugas-tugas Bahasa Indonesia seperti yang } \\
\text { diamanatkan pada pembelajaran daring pada saat pendemi ini. Tujuan penelitian ini } \\
\text { yakni untuk mendeskripsikan realisasi dan efektivitas pembelajaran daring pada } \\
\text { materi sastra di SMP Negeri } 1 \text { Pace. Penelitian ini menggunakan metode deskriptif } \\
\text { kualitatif. Subjek dalam penelitian ini adalah guru bahasa Indonesia dan siswa. Data } \\
\text { dikumpulkan dengan wawancara, dokumentasi, dan observasi. Hasil penelitian } \\
\text { menunjukkan realisasi pembelajaran daring di SMP Negeri } 1 \text { Pace menggunakan } 4 \\
\text { aplikasi, antara lain: whatsapp, youtube, Si Prestasi, dan AZ Screen recorder, dengan } \\
\text { media utama yang digunakan para guru berupa media power point. Efektivitas } \\
\text { pelaksanaannya ditunjukkan dengan tingkat keberhasilan pelaksanaan pembelajaran } \\
\text { daring di sekolah. Efektivitas evaluasi pelaksanaan pembelajaran daring ditunjukkan } \\
\text { berdasarkan tingkat keberhasilan evaluasi pembuatan persiapan pelaksanaan } \\
\text { pembelajaran daring, evaluasi pelaksanaan pembelajaran daring, dan evaluasi } \\
\text { penilaian pembelajaran daring. Sesuai hasil penelitian, efektivitas evaluasi } \\
\text { pelaksanaan pembelajaran daring telah mencapai } 83,3 \% \text { dengan kategori baik (B). }\end{array}$ \\
\hline \multicolumn{2}{|r|}{ Abstract } \\
\hline $\begin{array}{l}\text { Keywords: online, } \\
\text { learning, literature }\end{array}$ & $\begin{array}{l}\text { Learning at SMP Negeri } 1 \text { Pace, is still far from expectations. Many students who } \\
\text { lack discipline in submitting Indonesian assignments as mandated in online learning } \\
\text { during this pandemic. The purpose of this study is to describe the realization and } \\
\text { effectiveness of online learning on literary material at SMP Negeri } 1 \text { Pace. This } \\
\text { research uses a qualitative descriptive method. The subjects in this study were } \\
\text { Indonesian language teachers and students. Data were collected by interview, } \\
\text { documentation, and observation. The results showed the realization of online learning } \\
\text { at SMP Negeri } 1 \text { Pace using } 4 \text { applications, including: whatsapp, youtube, Si } \\
\text { Prestasi, and AZ Screen recorder, with the main media used by teachers in the form of } \\
\text { power point media. The effectiveness of its implementation is indicated by the success } \\
\text { rate of the implementation of online learning in schools. The effectiveness of the } \\
\text { evaluation of the implementation of online learning is shown based on the level of } \\
\text { success of the evaluation of the preparation for the implementation of online learning, } \\
\text { the evaluation of the implementation of online learning, and the evaluation of the } \\
\text { online learning assessment. According to the results of the study, the effectiveness of } \\
\text { the evaluation of the implementation of online learning has reached } 83.3 \% \text { with a } \\
\text { good category (B). }\end{array}$ \\
\hline $\begin{array}{l}\text { Diterima/direview/ } \\
\text { dipublikasi }\end{array}$ & 01 Agustus 2021/ 20 Agustus 2021/ 30 September 2021 \\
\hline
\end{tabular}




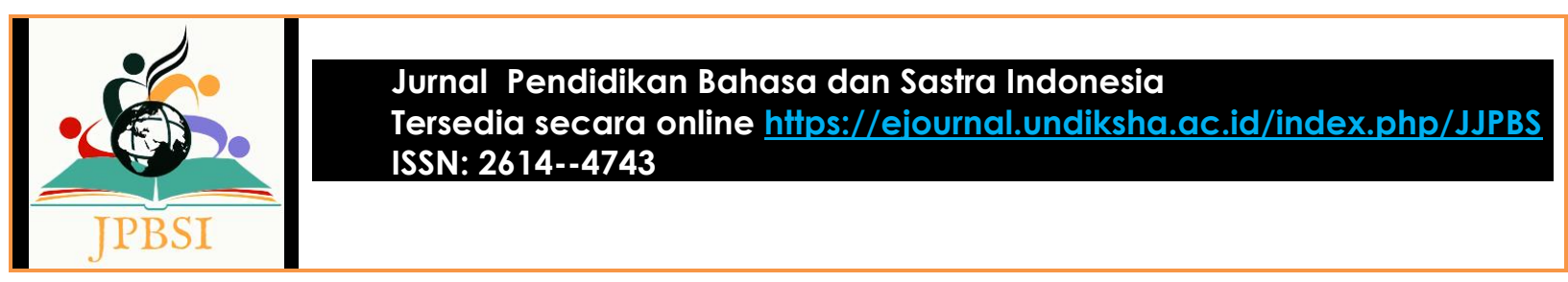

\section{PENDAHULUAN}

Pelaksanaan proses belajar mengajar pada masa pendemi ini harus melalui kegiatan daring. Salah satu penyebabnya adalah sekolah tidak boleh mengadakan pembelajaran di kelas. Sesuai dengan kenyataan, pembelajaran bahasa Indonesia terutama yang berhubungan dengan aspek-aspek kognitif dan psikomotor siswa dapat dilakukan melalui pembelajaran daring (E-learning (daring). Menurut Handarini (2020: 498) mengatakan bahwa adanya pembelajaran daring ini memberikan layanan pembelajaran bermutu dalam jaringan yang bersifat terbuka untuk menjangkau peminat ruang belajar agar lebih luas.

E-learning (daring) telah diperkenalkan sebagai media dalam proses pembelajaran di dunia internasional khususnya di perguruan tinggi. Hal ini tentunya akan berbeda jika dilakukan di SMP dan SMA. Di mana siswa akan memiliki sedikit ketergantungan pada gurunya, yang terbiasa menjelaskan di kelas melalui tatap muka. Ada beberapa hal yang harus dilakukan guru di antaranya membangun kesadaran dan memotivasi siswa dalam belajar, mendorong interaksi dan kolaborasi di antara siswa, membangun kelompok belajar dengan lingkungan online agar siswa tidak merasa belajar mandiri, dan menyikapi interaksi dan pantau kehadiran mereka saat online sebagai umpan balik dalam proses pembelajaran. (Khotimah, 2020).

Kondisi nyata yang terjadi pada saat pandemi ini pun, khususnya di SMP Negeri 1 Pace, masih jauh dari harapan. Kenyataannya masih banyak siswa yang kurang disiplin mengumpulkan tugas-tugas seperti yang diamanatkan pada pembelajaran daring yang saat ini telah ada. Banyak siswa yang tidak mengumpulkan tugas khususnya pada mata pelajaran Bahasa Indonesia membuat guru harus lebih kreatif lagi dalam menyusun dan melaksanakan penyampaian materi daring yang harus tersampaikan pada siswa. Jika hal ini terbiarkan maka prestasi pembelajaran Bahasa Indonesia, khususnya bidang sastra akan mengalami penurunan.

Ada beberapa aplikasi yang dapat membantu kegiatan belajar mengajar. Pemerintah juga mengambil peran dalam menangani ketimpangan kegiatan belajar selama pandemi covid-19 ini. Melihat situasi dan kondisi pada bidang pendidikan saat ini, pemerintah telah membuka publik khususnya bidang pendidikan untuk berpikir kreatif dan adaptif dengan mengubah model belajar mengajar yang semula berbasis konvensial menjadi pembelajaran berbasis e-learning (daring). Elearning (daring) atau Electronic Learning (pembelajaran elektronik) diartikan sebagai pembelajaran yang menggunakan media elektronik, atau menjalin hubungan melalui media elektronik, dalam hal ini dapat berupa komputer. E-learning (daring) sangat memudahkan pendidik untuk menyampaikan materi pembelajaran dan dengan tampilan menarik perhatian peserta didik untuk belajar matematika (Rodiawati, 2018:2). Aplikasi media elektronik tersebut misalnya whatsapp, zoom, web blog, edmodo, google meet, dan lain-lain.

Pemanfaatan e-learning (daring) memberikan banyak kemudahan, salah satunya dalam pembelajaran bahasa Indonesia. Syrtsova, dkk (2017) mengemukakan bahwa e-learning (daring) adalah proses inovatif dengan penggunaan sarana teknis modern, metode pendidikan yang efektif yang membuat proses pembelajaran menjadi jelas, secara visual dan dapat diakses oleh semua orang. Hal ini sejalan dengan pernyataan Kusumastuti, dkk (2020:1073) bahwa tujuan e-learning (daring) adalah untuk membantu organisasi dalam menyediakan konten e-learning (daring) dan menyediakan interaksi kapan saja dan di mana saja untuk berkontribusi pada proses pembelajaran.

Salah satu tahapan penting dalam pengembangan e-learning (daring) adalah evaluasi yang bertujuan untuk mengetahui kualitas e-learning (daring) yang dikembangkan. Menurut Simanihuruk, dkk, (2019) evaluasi e-learning (daring) dibagi menjadi dua yaitu: (1) Evaluasi formatif; evaluasi yang dilakukan ketika proses pengembangan tengah berlangsung dengan tujuan mengidentifikasi sebanyak mungkin kekurangan dalam produk sehingga pengembang dapat melakukan revisi sebelum 


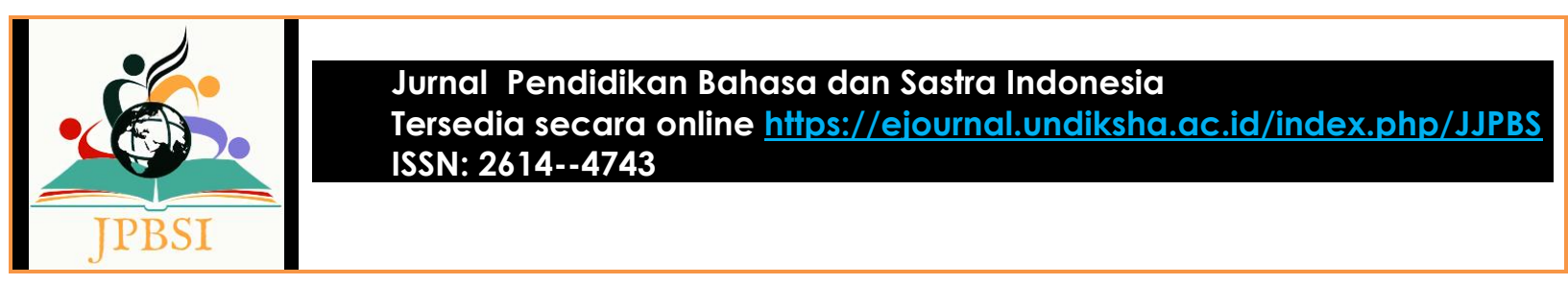

dipakai oleh pengguna. Adapun tahap evaluasi formatif yaitu ongoing evaluation, alpha testing dan beta testing; dan (2) Evaluasi sumatif; evaluasi yang dilakukan untuk mengetahui dampak penggunaan e-learning (daring) secara luas, menentukan kebermaknaan program dalam hal efektifitas, efisiensi, dan daya tarik. Juga untuk mengetahui apakah ada nilai tambah setelah menggunakan e-learning (daring), serta untuk memutuskan apakah program e-learning (daring) akan digunakan apa adanya, direvisi atau dihentikan penggunaannya.

Simanihuruk, dkk, (2019) mengemukakan Learning Object Review Instrument (LORI) untuk mengevaluasi e-learning (daring) dengan kriteria penilaian: (1) Content quality; ketelitian, akurasi, keseimbangan ide, ketepatan tingkatan; (2) Learning goal alignment; keselarasan antara tujuan pembelajaran, ketepatan dan karakter peserta didik; (3) Feedback \& adaptation; adaptasi terhadap umpan balik dari masukan peserta didik; (4) Motivation; kemampuan untuk memberikan motivasi kepada peserta didik; (5) Presentation design; ketepatan penyajian informasi berupa audio atau visual untuk meningkatkan proses belajar; (6) Interaction usability; kemudahan navigasi, user interface yang mudah dipahami dan kualitas fitur bantuan; (7) Accessability; kemampuan untuk mengakses media; (8) Reusability, kemampuan untuk dapat digunakan pada platform yang berbeda; (9) Standard complience; kesesuaian dengan standard internasional yang berlaku.

Fokus pada penelitian ini adalah pembahasan mengenai realisasi dan efektivitas pembelajaran daring pada materi sastra Indonesia di kelas VII SMP Negeri 1 Pace. Berdasarkan hal tersebut, peneliti memandang perlu dilakukan penelitian dengan judul "Realisasi Pembelajaran dalam Jaringan pada Pelajaran Bahasa Indonesia di Sekolah Menengah Pertama". Adapun tujuan penelitian ini yakni untuk mendeskripsikan realisasi dan efektivitas pembelajaran daring pada materi sastra Indonesia di kelas VII SMP Negeri 1 Pace.

Hasil penelitian ini dapat dimanfaatkan dalam pembelajaran sastra di SMP kelas VII yaitu berupa mendapatkan informasi tentang realisasi pembelajaran daring pada materi sastra, dapat mengembangkan pembelajaran dengan menggunakan model e-learning atau daring, membantu meningkatkan prestasi belajar siswa khususnya bahasa Indonesia melalui kegiatan daring, dapat meningkatkan motivasi dan aktivitas siswa untuk belajar lebih aktif dan kreatif, menumbuhkan rasa suka, meningkatkan apresiasi siswa, dan menumbuhkan motivasi intrinsik, serta saling bekerja sama antarsiswa, sehingga prestasi belajar bahasa Indonesia khususnya materi sastra bisa meningkat.

Dengan demikian, realisasi pembelajaran daring pada pelajaran bahasa Indonesia khususnya di bidang sastra dilakukan untuk mengetahui seberapa jauh keberhasilan proses pembelajaran. Materi sastra dalam jaringan di kelas VII SMP Negeri 1 Pace yang digunakan dalam pembelajaran adalah mencipta cerita fantasi (semester 1); mewarisi nilai luhur dan mengkreasikan puisi rakyat (semester 2); dan mengapresiasi dan menulis puisi baru (semester 2).

\section{METODE PENELITIAN}

Metode penelitian yang digunakan oleh penulis untuk memperoleh data adalah metode deskriptif kualitatif. Penulis bertujuan mendeskripsikan realisasi pembelajaran daring pada materi sastra di SMP Negeri 1 Pace. Penggunaan internet sebagai penunjang sesuai dengan data yang diteliti yaitu melalui pengumpulan data yang kemudian disusun, dianalisis dan ditafsirkan.

Data materi pembelajaran dan evaluasi sastra di kelas VII, diteliti tingkat realisasinya. Ada beberapa metode yang dapat digunakan untuk mempelajari masalah tersebut. Pertama, metode wawancara, peneliti dapat mengajukan pertanyaan-pertanyaan secara mendalam dan dapat mengulangi pertanyaan pada informan serta informan dapat menjawab dengan cepat sesuai dengan kemampuannya. Kedua metode angket, peneliti dapat menggunakan angket (bahan tertulis) yang diharapkan dapat memberikan hasil yang lebih baik. Ketiga metode observasi, yakni peneliti menggunakan rekaman tuturan dalam percakapan antara dua informan, yakni guru yang mengajarkan 


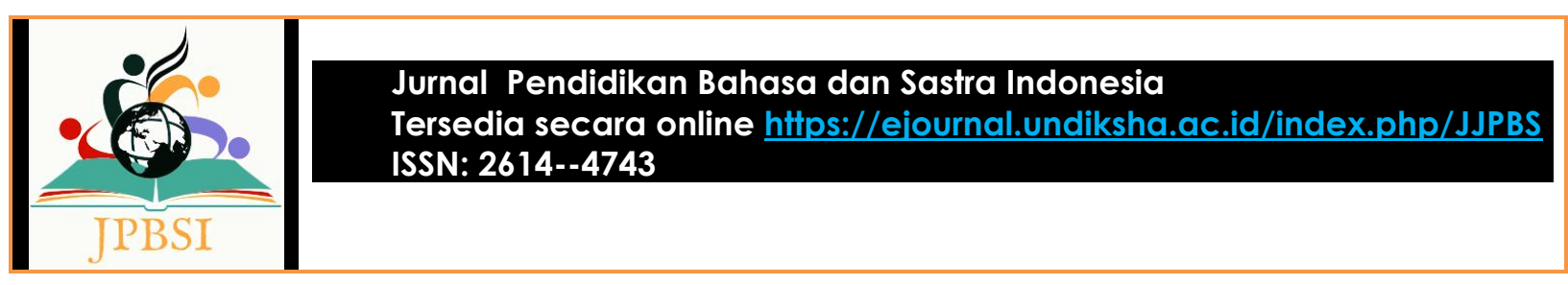

materi sastra secara daring dan melihat hasil rekamannya melalui youtube untuk mengamati hasil evaluasi yang diharapkan oleh guru pengampuya.

Langkah-langkah umum yang perlu ditempuh dalam desain penelitian deskriptif ini adalah sebagai berikut: (1) Memilih dan merumuskan masalah; (2) Menentukan tujuan penelitian; (3) Memberikan limitasi atau ruang lingkup penelitian (pembatasan masalah); (4) Merumuskan kerangka teori yang relevan; (5) Melakukan kerja lapangan untuk mengumpulkan data, menggunakan teknik pengumpulan data yang cocok untuk penelitian; (6) Membuat laporan penelitian secara ilmiah. Subjek dalam penelitian ini adalah guru bahasa Indonesia dan siswa.

Teknik pengumpulan data yang digunakan dalam penelitian ini adalah wawancara, dokumentasi, dan observasi. Teknik dokumentasi dalam penelitian ini merupakan metode inti. Data yang akan dikumpulkan dari teknik dokumentasi ini adalah bahan atau materi yang akan digunakan dalam pelaksanaan/pengadaan pembelajaran daring. Bahan dokumen dapat diambil dari youtube pembelajaran bahasa Indonesia pada SMP Negeri 1 Pace. Melalui observasi pada materi pembelajaran dari youtube diperoleh data tambahan untuk melengkapi data inti yang ada berdasarkan materi pembelajaran yang diambil berdasarkan perangkat pembelajaran bahasa Indonesia kelas VII semester I dan II.

Analisis data yang digunakan sesuai dengan teori Huberman. Menurut Huberman (2004 : 21 - 23) bahwa langkah yang dapat ditempuh dalam menganalisis data penelitian kualitatif, adalah (1) mereduksi data, (2) paparan atau penyajian data, (3) penarikan kesimpulan. Analisis yang dilakukan setelah masa pengumpulan data berakhir adalah berupa mempelajari kembali keseluruhan analisis yang sudah pernah dilakukan sebelumnya (selama masa pengumpulan data). Kegiatan yang dilakukan tahap ini berupa penambahan, pengembangan, dan perbaikan-perbaikan, serta penarikan kesimpulan sementara. Selain pada tahap ini juga dilakukan analisis data hasil wawancara dengan subjek penelitian yang dilakukan pada hari-hari terakhir penelitian.

Keabsahan data dalam penelitian ini menggunakan triangulasi teori. Menurut Mamik (2015:118), triangulasi teori merupakan hasil akhir penelitian kualitatif yang berupa rumusan informatif. Informasi yang dihasilkan kemudian dibandingkan dengan teori yang relevan, sehingga menghindari perbedaan hasil dari individual peneliti. Penelitian ini dilakukan dengan mengkaji berbagai teori yang relevan tentang evaluasi penerapan e-learning (daring) pada pembelajaran sastra.

\section{HASIL DAN PEMBAHASAN}

\section{Realisasi Pelaksanaan Pambelajaran Daring}

Pembelajaran daring penuh merupakan pembelajaran yang telah dilaksanakan di SMP Negeri 1 Pace, Kabupaten Nganjuk, Jawa Timur sejak bulan Agustus 2020. Pada proses pembelajaran mata pelajaran Bahasa Indonesia ini, diketahui guru dan siswa sepakat untuk menggunakan 4 aplikasi, antara lain: whatsapp, youtube, Si Prestasi, dan AZ Screen recorder. Sementara media utama yang digunakan para guru adalah media power point. Sedangkan media pendukung lainnya berupa buku bacaan wajib, print out materi, dan sebagian guru menggunakan LKS.

Realisasi pembelajaran daring, meliputi persiapan yang telah dilakukan secara matang oleh guru mata pelajaran masing-masing. Sesuai hasil wawancara peneliti, berbagai persiapan secara tertulis telah dilakukan oleh guru. Persiapan tertulis itu antara lain, mulai dari: menyusunan perangkat RPP dan sejenisnya, mempersiapkan media pembelajaran, mempersiapkan materi sebelum mengajar, menentukan metode mengajar, mamahami karakter siswa, dan pengadaan alat peraga dan perpustakan.

Pada tahap persiapan ini, guru membuat media ajar untuk bahan penyampaian materi daring yang akan disampaikan sesuai jadwal yang ada. Sejumlah media power point harus dipersiapkan guru 


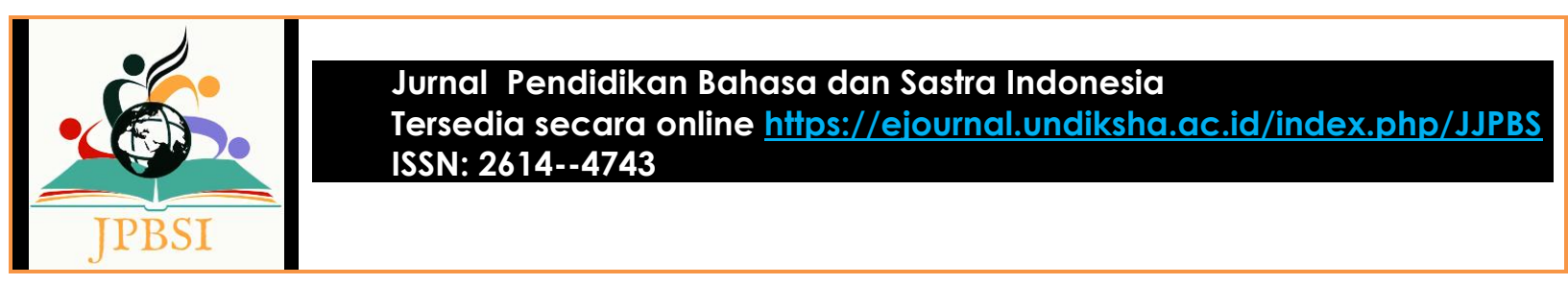

sesuai materi yang ada. Materi mencipta cerita fantasi yang akan disampaikan antara lain: (1) pengertian dan tujuan teks cerita fantasi; (2) ciri-ciri teks cerita fantasi; (3) struktur teks cerita fantasi; (4) jenis teks cerita fantasi; dan (5) mencipta cerita fantasi. Persiapan materi kedua tentang mewarisi nilai luhur dan mengkreasikan puisi rakyat, telah dipersiapkan 10 slide untuk ditayangkan kepada siswa, diantaranya slide tentang: (1) mewarisi nilai luhur dan mengkreasikan puisi rakyat, (2) asal dan jenis puisi rakyat, (3) ciri-ciri gurindam, (4) asal puisi pantun, (5) ciri rakyat berjenis pantun, (6) istilah syair, (7) ciri-ciri syair, (8) kebahasaan puisi lama, (9) jenis kata penghubung, dan (10) kalimat majemuk dalam puisi rakyat. Persiapan materi ketiga tentang mengapresiasi dan menulis puisi baru dibutuhkan 5 slide, diantaranya slide tentang: (1) judul Penulisan Puisi, (2) langkah-langkah menulis puisi, (3) data hasil pengamatan, (4) deretan kata-kata hasil pengamatan yang sudah dibumbui dengan pencitraan, dan (5) hasil larik-larik puisi yang siap untuk diedit dan diberi judul.

Realisasi persiapan pembelajaran daring di atas kurang sesuai dengan hasil penelitian terdahulu dengan judul Analisis Keefektifan Pembelajaran Online di Masa Pandemi Covid-19 oleh Briliannur Dwi C, dkk (2020). Hasil dari penelitian tersebut adalah kurang efektifnya pembelajaran online karena faktor kurangnya sarana dan prasarana serta ketidaksiapan edukasi teknologi. Sementara di SMP Negeri 1 Pace untuk pembelajaran daring sudah menggunakan 4 aplikasi yang bervariasi, termasuk media belajar yang dipersiapakan oleh guru sudah berkategori baik. Realisasi pembelajaran daring dalam pelaksanaannya, persiapannya harus dilakukan secara matang.

Dalam pelaksanaan pembelajaran daring perlu dilakukan langkah penentu keberhasilan suatu kegiatan belajar mengajar. Menurut Wijaya (2017) e-learning memiliki karakteristik, antara lain yaitu 1) interactivity (interaktivitas); 2) independency (kemandirian); 3) accessibility (aksesibilitas); dan 4) enrichment (pengayaan).

Karakteristik pertama adalah interactivity (interaktivitas). Materi yang disampaikan oleh pengajar bisa menimbulkan interaksi dengan peserta didik. Peserta didik bisa menganalisis materi yang disampaikan oleh pegajar dan bisa menindaklanjutinya dengan bertanya atau menjawab tugas yang diberikan secara daring. Pertanyaan bisa disampaikan melalui WhatsApp group kelas. Karakteristik kedua adalah independency (kemandirian). Melalui pembelajaran daring, peserta didik bisa belajar secara mandiri. Membaca dan mendengarkan siaran pengajar melalui AZ screen recorder, youtube, maupun WhatsApp. Dari menyerap materi hingga mengerjakan tugas siswa bisa bekerja secara mandiri. Karakteristik ketiga adalah accessibility (aksesibilitas). Pembelajaran daring memudahkan akses dalam mencari materi pembelajaran yang harus dipelajari peserta didik. Dengan melalui youtube tersedia materi pokok maupun materi tambahan atau materi pendamping yang arus dipelajari peserta didik. Karakteristik keempat pembelajaran daring adalah enrichment (pengayaan). Materi mencipta cerita fantasi yang disampaikan pengajar melalui $A Z$ screen recorder, bisa dipakai peserta didik sebagai bahan pengayaan. Selain melalui buku sebagai bahan pustaka wajib, materi dalam $A Z$ screen recorder bisa dibaca atau dilhat berulang-ulang sebagai bahan mengayaan mereka.

Penilaian pembelajaran daring sangat tepat digunakan untuk meningkatkan proses belajar, mudah dipahami, dan kualitas fitur bantuan. Melalui pembelajaran daring ini kemampuan untuk mengakses media peserta didik sangat bisa terlihat. Penilain daring ini juga sesuai dengan standard internasional yang berlaku.

\section{Efektivitas Pelaksanaan Pembelajaran Daring}

Sesuai pendapat Bates (2020:52) pembelajaran daring merupakan bentuk pendidikan jarak jauh yang penyampaian materinya dilakukan melalui internet (dalam jaringan). Efektivitas pembelajaran daring merupakan ukuran keberhasilan dari suatu proses interaksi antar siswa maupun antara siswa dengan guru dalam situasi edukatif untuk mencapai tujuan pembelajaran secara daring. Berdasarkan data yang diperoleh dalam penelitian ini, efektivitas pembelajaran daring dikelompokkan dalam tiga 


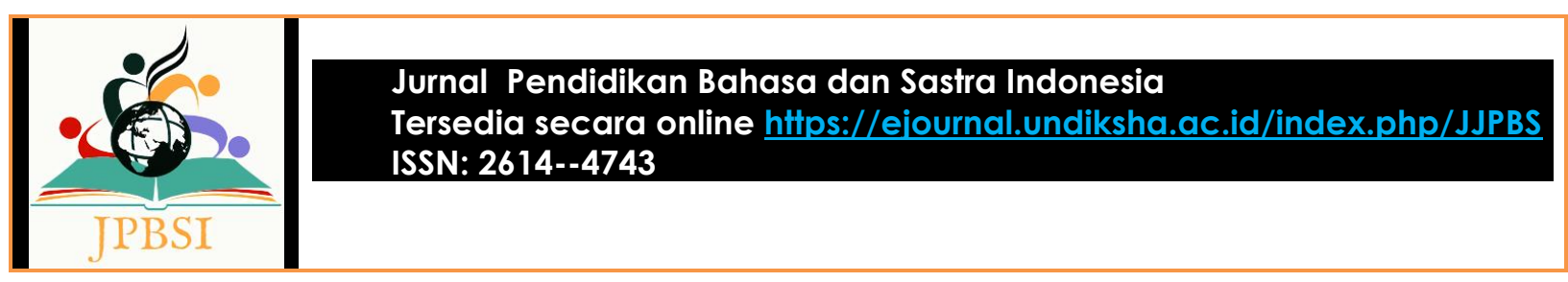

kategori. Pertama, efektivitas persiapan realisasi pembelajaran daring, kedua, efektivitas pelaksanaan pembelajaran daring, dan ketiga, efektivitas evaluasi pelaksanaan pembelajaran daring.

Efektivitas persiapan realisasi pembelajaran daring ditunjukkan dengan tingkat keberhasilan persiapan bahan ajar yang telah dibuat oleh guru sebelum pelaksanaan pembelajaran daring berlangsung. Berdasarkan data yang diperoleh, efektivitas persiapan pembelajaran daring ini telah mencapai 81,2\% dengan kategori baik (B). Angka tersebut diperoleh dari rata-rata persiapan untuk tiga materi pembelajaran, yakni: (1) persiapan bahan ajar 1 tentang materi pokok menulis teks cerita fantasi mencapai 83,3\% dengan kategori baik (B); (2) persiapan bahan ajar 2 tentang mewarisi nilainilai luhur dan mengkreasikan puisi rakyat mencapai 76,9\% dengan kategori baik (B); dan (3) persiapan bahan ajar 3 tentang mengapresiasi dan menulis puisi baru mencapai 83,3\% atau dengan kategori baik (B).

Efektivitas pelaksanaan pembelajaran daring ditunjukkan dengan tingkat keberhasilan pelaksanaan pembelajaran daring di sekolah. Efektivitas pelaksanaan pembelajaran daring di SMP Negeri 1 ini telah mencapai 92,3\% atau dengan kategori A (amat baik). Hasil tersebut didapat dari rata-rata lima kegiatan guru dan siswa saat pembelajaran KBM berlangsung. Lima kegiatan tersebut efektivitasnya mencapai angka yang bervariasi, yakni: (1) persiapan materi mencapai $86,4 \%$ dengan kategori baik; (2) pemanfaatan media mencapai $75 \%$ dengan kategori baik; (3) penggunaan aplikasi mencapai $100 \%$ dengan kategori amat baik; (4) penugasan siswa mencapai $100 \%$ dengan kategori amat baik; dan (5) respon siswa mencapai 100\% dengan kategori amat baik.

Berdasarkan paparan data diatas, dapat diungkapkan kembali melalui Tabel 01 berikut ini:

Tabel 01 Efektivitas Pelaksanaan Pembelajaran Daring

\begin{tabular}{|c|l|c|c|c|}
\hline No & Kegiatan Pelaksanaan Pembelajaran Daring & Kebutuhan & Dilaksanakan & Keberhasilan \\
\hline 1 & Persiapan materi pembelajaran & 22 slide & 19 slide & $86,4 \%$ \\
\hline 2 & Pemanfaatan media belajar & 4 media & 3 media & $75 \%$ \\
\hline 3 & Penggunaan aplikasi & 4 media & 4 media & $100 \%$ \\
\hline 4 & Penugasan Siswa & 6 tugas & 6 tugas & $100 \%$ \\
\hline 5 & Respon siswa & 4 respon & 4 respon & $100 \%$ \\
\hline & Rata-rata Keberhasilan & & & $92,3 \%$ \\
\hline & Tingkat efektivitas & & & A (amat afektif) \\
\hline
\end{tabular}

Sumber Data : Hasil Olahan Peneliti, 2021

Berdasarkan Tabel 01 diatas, efektivitas pelaksanaan pembelajaran daring di SMP Negeri 1 Pace dideskripsikan sebagai berikut: Pertama, persiapan materi pembelajaran seharusnya dibuat 22 slide, tetapi hanya dibuat 19 slide, sehingga tingkat keberhasilannya hanya mencapai 86,4\%. Kedua, pemanfaatan media belajar seharusnya memanfaatkan 4 media (mulai dari power point, print out materi, LKS, dan buku paket), namun hanya dimanfaatkan 3 media, sehingga tingkat efektivitas keberhasilan pemanfaatan media hanya mencapai $75 \%$. Ketiga, penggunaan aplikasi seharusnya menggunakan 4 aplikasi (Whatsapp, AZ Screen recorder, Si Prestasi, dan Youtube), semua aplikasi digunakan semua, sehingga tingkat efeltivitas keberhasilannya sudah mencapai $100 \%$. Keempat, penugasan Siswa seharusnya siswa mengerjakan 6 kali tugas dan semua tugas sudah dikerjakan oleh siswa. Dengan demikian efektivitas penugasan sudah mencapai $100 \%$. Kelima, respon siswa seharusnya dilaksanakan 4 respon, yakni respon untuk: memperhatikan penjelasan guru, menyampaikan pendapatnya atau menjawab pertanyaan-pertanyaan, merangkum dari penjelasan guru, dan mengirimkan jawaban. Siswa telah melaksanakan 4 respon tersebut, dengan demikian efektivitas respon siswa sudah mencapai $100 \%$. Dari kelima kegiatan dalam pelaksanaan pembelajaran daring di atas, jumlah rata-rata efektivitas keberhasilan pelaksanaan pembelajaran daring mencapai $92,3 \%$ atau dengan kategori A (amat baik). 


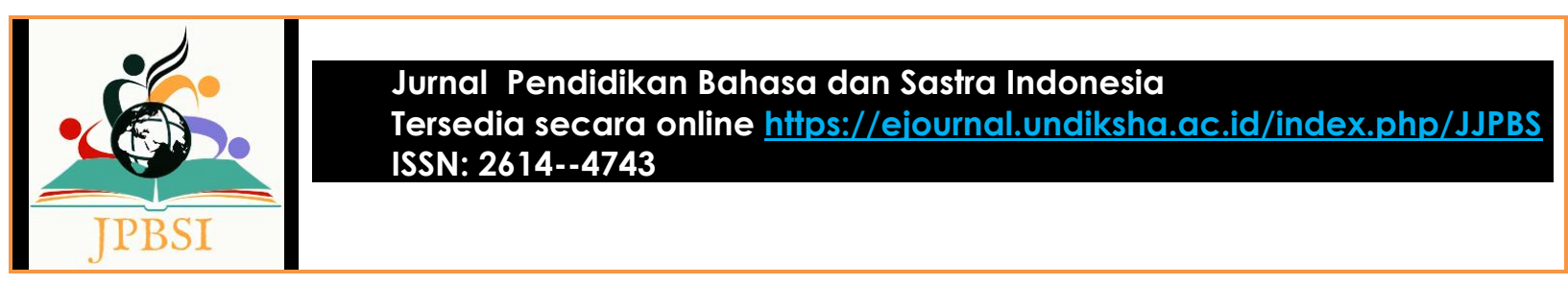

Efektivitas evaluasi pelaksanaan pembelajaran daring ditunjukkan berdasarkan tingkat keberhasilan pelaksanaan evaluasi pembelajaran daring meliputi evaluasi pembuatan persiapan pelaksanaan pembelajaran daring, evaluasi pelaksanaan pembelajaran daring, dan evaluasi penilaian pembelajaran daring. Sesuai hasil analisis data hasil penelitian, efektivitas evaluasi pelaksanaan pembelajaran daring telah mencapai 83,3\% dengan kategori baik (B).

Hasil tersebut merupakan hasil evaluasi kegiatan guru dalam pembelajaran daring mulai dari persiapan, pelaksanaan, hingga evaluasi pelaksanaan. Sejumlah 24 kegiatan yang seharusnya dilaksanakan oleh guru, hanya tercapai 20 kegiatan. Empat kegiatan yang tidak terlaksana dalam pembelajaran daring di antaranya kegiatan: (1) mengajak diskusi siswa; (2) mendiskusikan hasil tugas siswa; (3) memberikan refleksi pembelajaran; dan (4) memberikan penilaian kelompok.

Efektivitas pelaksanaan pembelajaran daring di atas sesuai dengan hasil penelitian terdahulu dengan judul Efektivitas Pembelajaran Daring Menggunakan Media Online Selama Pandemi Covid19 pada Mata Pelajaran Matematika; oleh Mustakim (2020). Berdasarkan hasil penelitian tersebut, peserta didik menilai pembelajaran matematika menggunakan media online sangat efektif $(23,3 \%)$, sebagian besar mereka menilai efektif (46,7\%), dan menilai biasa saja (20\%).

Meskipun ada juga peserta didik yang menganggap pembelajaran daring tidak efektif $(10 \%)$, dan sama sekali tidak ada (0\%) yang menilai sangat tidak efektif. Namun peneiiti tetap sependapat dengan hasil observasi yang ada, bahwa dengan pembelajaran daring, siswa masih bisa belajar lebih mandiri dengan materi yang bisa dibuka atau dibaca sewaktu-waktu.

\section{PENUTUP}

Beberapa kelebihan pelaksanaan pembelajaran daring, antara lain tidak terbatas jarak, tidak perlu bertemu secara langsung, dapat digunakan oleh banyak orang, mempercepat proses pembelajaran seperti mengirim file, googling dan sebagainya, mempermudah proses interaksi antar guru dan siswa, dan terus mengalami perkembangan. Sedangkan kelemahan pelaksanaan pembelajaran daring, antara lain memerlukan koneksi internet yang cukup cepat dan stabil, membutuhkan perangkat pintar seperti android atau laptop yang memadai, pembalajaran daring tergolong sulit dan susah untuk dipahami, tidak adanya interaksi secara langsung yang bisa menghambat proses belajar, sulit mengontrol siswa yang aktif atau tidak aktif, dan bersifat teoretis, kurang praktikum. Efektivitas pelaksanaan pembelajaran daring ditunjukkan dengan tingkat keberhasilan pelaksanaan pembelajaran daring di sekolah. Efektivitas pelaksanaan pembelajaran daring di SMP Negeri 1 ini telah mencapai 92,3\% atau dengan kategori A (amat baik). Hasil tersebut didapat dari rata-rata lima kegiatan guru dan siswa saat pembelajaran KBM berlangsung. Lima kegiatan tersebut efektivitasnya mencapai angka yang bervariasi, yakni persiapan materi mencapai 86,4\% dengan kategori baik, pemanfaatan media mencapai $75 \%$ dengan kategori baik, penggunaan aplikasi mencapai $100 \%$ dengan kategori amat baik, penugasan siswa mencapai $100 \%$ dengan kategori amat baik, dan respons siswa mencapai $100 \%$ dengan kategori amat baik. Efektivitas evaluasi pelaksanaan pembelajaran daring ditunjukkan berdasarkan tingkat keberhasilan pelaksanaan evaluasi pembelajaran daring meliputi evaluasi pembuatan persiapan pelaksanaan pembelajaran daring, evaluasi pelaksanaan pembelajaran daring, dan evaluasi penilaian pembelajaran daring. Sesuai hasil analisis data hasil penelitian, efektivitas evaluasi pelaksanaan pembelajaran daring telah mencapai 83,3\% dengan kategori baik (B).

\section{DAFTAR PUSTAKA}

Bates, A. W. (2020). Technology, E-learning and Distance Education (2nd ed.). Routledge.

Briliannur, Dwi, C., Ameli, A., Hasanah, U., Rahman, H., \& Putra, A. M. 2020. Analisis Keefektifan Pembelajaran Online di Masa Pandemi Covid-19. Mahaguru: Jurnal Pendidikan Guru Sekolah Dasar. 2(1), 28-37. 


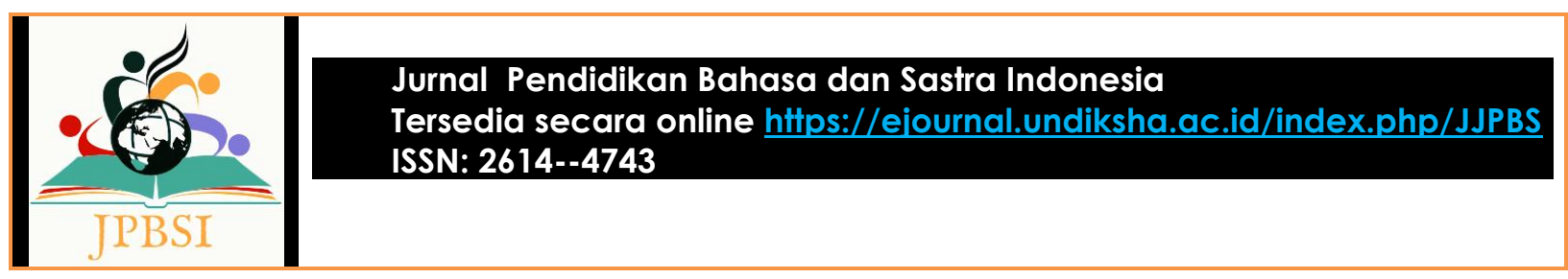

Handarini, Oktafia Ika, and Siti Sri Wulandari. (2020). Pembelajaran daring sebagai upaya study from home (SFH) selama pandemi covid 19.Jurnal Pendidikan Administrasi Perkantoran (JPAP) 8(3), 496-503.

Khotimah, Husnul., Zainiyati, H. S., Hamid, A., \& Basit, A. (2020). E-learning (daring) Application Madrasah Online Learning Solution In The Middle of Pandemic Covid-19 in MA Negeri Insan Cendekia, Kendari. Technium Social Sciences Journal. Vol. 10, 107-114.

Kusumastuti, Dyah., Soesanto, R. P., Kurniawati, A., \& Teguh, M. (2020). E-learning (daring) Content Design using ADDIE and SECI: Case of Shelving Activity in Research Organization. 10(3), 1072-1077.

Mamik. (2015). Metodologi Kualitatif. Sidoarjo: Zifatama Publisher

Mustakim, M. (2020). Efektivitas pembelajaran daring menggunakan media online selama pandemi covid-19 pada mata pelajaran matematika. Al asma: Journal of Islamic Education 2(1), 1-12.

Rodiawati, Heni., \& Komarudin. (2020). Pengembangan E-learning (daring) Melalui Modul Interaktif Berbasis Learning Content Development System. Jurnal Tatsqif: Jurnal Pemikiran dan Penelitian Pendidikan. 16(2), 172-185.

Simanihuruk, Lidia, dkk. (2019). E-learning (daring): Implementasi, Strategi dan Inovasinya. Jakarta: Penerbit Yayasan Kita Menulis

Syrtsova, Elena., Tokmakova, O., Merkulova, I., \& Sinitsyna, O. (2017). E-learning (daring) System Development In Accordance With The Requirements Of Efquel: Vyatka State University Experience. International Journal for Quality Research. 11(2), 379-396.

Wijaya, I. G. N. S., \& Suwastika, I. W. K. (2017). Analisis Kepuasan Pengguna E-Learning Menggunakan Metode Kano. Jurnal Sistem dan Informatika (JSI). 12(1), 128-138.

Copyright holder: @ Rachmah, S. \& Huda, S. (2021)

Fist publication right: Jurnal Pendidikan Bahasa dan Sastra Indonesia Undiksha

cc) (i) (2) 